\title{
ARCHIVES AS INFORMATION INFRASTRUCTURE AND THEIR URGENCY TOWARD RESEARCH
}

\author{
L. Nurdin*
}

*Library Science Study Program, Faculty of Adab and Cultural Studies Universitas Islam Negeri Sunan Kalijaga Yogyakarta

Email: nurdin@uin-suka.ac.id

(Submitted: 02-01-2021, Revised: 06-05-2021, Accepted: 09-05-2021) DOI: $10.24252 / v 9 i 1 \mathrm{a} 4$

\begin{abstract}
ABSTRAK: Arsip dipandang sebagai sumber utama penelitian. Dengan demikian, sangat mendasar dan mendesak bagi peneliti mengenai data yang akan digunakan dan keakuratannya dapat diandalkan. Penelitian ini dilakukan untuk mengkaji arsip sebagai infrastruktur informasi dalam penelitian. Penelitian ini menggunakan metode deskriptif kualitatif dalam bingkai pendekatan konstruktivis dalam membaca fenomena Arsip UIN Sunan Kalijaga. Pengumpulan data dilakukan dengan menggunakan tiga teknik utama, yaitu wawancara, observasi, dan dokumentasi. Hasil penelitian menemukan tiga isu penting terkait keberadaan arsip sebagai infrastruktur informasi penelitian, yaitu arsip sebagai sarana pelestarian sejarah, dokumen primer, dan modal pengembangan penelitian. Sebagai kurator sejarah, tampaknya fungsinya sangat penting dalam penelitian sejarah karena kelahirannya tidak dimaksudkan untuk menghasilkan bahan-bahan sejarah, tetapi lahir dengan sendirinya mengikuti interaksi masyarakat. Sebagai dokumen primer, arsip menjadi penting karena lahir bersamaan dengan peristiwa, bukan dari cerita aktor sosial. Adapun dalam rangka modal pengembangan penelitian, arsip merupakan sumber yang memiliki tingkat ketelitian yang tinggi, sehingga fungsinya dalam penelitian sangat penting untuk menghasilkan penelitian yang berkualitas.
\end{abstract}

Kata kunci: Arsip universitas; infrastruktur informasi; sumber modal penelitian

ABSTRACT: Archives are primary sources for research. Thus, it is very fundamental and urgent for researchers regarding the data to be used and their accuracy is reliable. This research was conducted to investigate archives as information infrastructure in research. The research used a qualitative descriptive method in the frame of a constructivist approach in reading the phenomena of UIN Sunan Kalijaga Archives. The data collection was carried out using three main techniques, namely interview, observation, and documentation. The study found three important issues related to the existence of archives as information infrastructure on research, i.e., archives as a means of historical preservation, primary document, and research development capital. As a curator of history, it seems that its function is very important in historical research because its birth was not intended to produce historical materials, but was born by itself following the interaction of the people. As a primary document, archives are important because they were born simultaneously with events, not from the stories of social actors. As for the framework of research development capital, archives are a source that has a high degree of accuracy, so that its function in research is very important to produce qualified research.

Keywords: University archives; information infrastructures; research capital resources

\section{INTRODUCTION}

Archives are records of individual and collective memories (Jeon, 2011; Sande, Verborgh, Hochstenbach, \& Sompel, 2018), in the form of dynamic and static archives (Indonesia, 2009). Dynamic archives are actively used in personal and group activities so that their existence is 
important. Meanwhile, static archives whose management is still limited and even neglected seem insignificant in people's lives, even though their existence is very urgent for the social and legal sustainability of individuals and institutions (Mirwani, 2014). Static archives also serve as a foundation infrastructure for developing knowledge to understand past events (Blouin, 1999; Larsen, 2018). As a foundation, this archive records every individual and group event within the institution which can be referred to for any planning of action, especially as a reference for research. Both strategic planning and research are based on knowledge of past events. Without such knowledge, a plan or research has the potential to give birth to speculative actions that are very risky.

To achieve major research based on primary sources, the management of archives as an information infrastructure is a key factor. Since the beginning of Independence Day, the Government of Indonesia has started to manage state archives until the issuance of Law Number 7, 1971 concerning Archive Management, although the management seems limited and still stops in the preservation vortex. Many excuses are still open and occurred because this Law still focuses on the responsibility for managing and preserving archives in the hands of ANRI (National Archives of the Republic of Indonesia). For this reason, Law number 43, 2009 was issued as an effort to involve universities in managing their archives for research and academic purposes. Blendon (1975), Nesmith (2002), Jeon (2011), and Beard (2018) showed the importance of university archives in helping the realization of academic research at universities. This is understandable because archives are actual information about institutional development policies and programs.

The presence of archives in the world of research is important for several reasons. First, archives as records from past events are primary information as one of the main bases for quality research. The quality of research is a non-negotiable aspect of knowledge development. Second, the archive is a gradual source containing actual information on the events it has experienced, so it is very accurate and reliable as research data. Reliability of information is one of the keys to the truth of knowledge. Third, the archive as a medium contains natural messages about the era and situation that occurred in an institution or society under certain conditions. Archives are primary texts, which are relatively far from second-party interpretations and constructs (Jones, 2010) so that the originality of events can be maintained. The importance of archive will be seen in UIN Sunan Kalijaga Archives regarding its governance and potential as an information infrastructure and its urgency in research.

\section{PREVIOUS FINDINGS}

Widarno (2010) described archives in three concepts, first as documents or notes that are of immortal value. Second, the archive is a storage area for archives. Third, archives are understood as an organization that is responsible for assessing, collecting, and preserving important documents/records. This understanding is in line with Government Regulation Number 34, 1979 and Law Number 43, 2009, which describes archives as records of activities in various forms and media under developments in information and communication technology that are made and accepted by state institutions, local governments, educational institutions, companies, political organizations, community organizations, and individuals in the implementation of life in society, nation, and state (Larsen, 2018; Lian, 2017).

In the context of university archives, according to Purcell (2012), those are placed at university libraries or are part of separate collections at universities. Widarno (2010) stated that university archives are an integrated program covering policies, human resources, activities and facilities to preserve archives and manage university documents as a legacy that needs to be served for the benefit of users. Blendon (1975) and Noble (1977) described university archives as an important source of information in various fields, such as records of institutional events that tell about institutional life, records of intellectual events, social and political records amongst academics and society, and edits of news related to the packaging of event information.

The function of university archives by Widarno (2010) is described in seven points. First, assessing, storing, managing, processing, presenting, and maintaining high-value archives; 
second, providing facilities for retention and preservation activities; third, providing information services to assist the implementation of university activities; fourth, providing research services through the provision of archives; fifth, disseminating the objectives, programs, targets and potential of university development; sixth, facilitate efficient archiving activities; seventh, providing information resources for teaching that stimulates creativity. Besides, archives are generally divided into two types, namely dynamic and static (Indonesia, 2009). The dynamic archive is an archive that is ongoing used in the activities of an archive creator and is stored for a certain period, while a static archive is a document that has historical use-value, expires retention, and has permanent information.

Regarding archive management, according to Hunter (2003), Purcell (2012), and Wursanto (1991), it is carried out in several stages. The first is selection and appraisal as a policy for selecting and determining use-value, administration, law, finance, evidence, and information. Second, namely acquisition and access to procurement and services. In an acquisition, there are three principal methods of archive procurement, namely: transfers in institutions, purchases, and gifts, while access is understood as an act and procedure in using an archive through three forms of supervision, namely legal, physical, and intellectual. Legal control is carried out through oral agreements, purchases, letters, wishes, deposits, and gifts. Physical control is in the form of sending and documentation of collection notes. Meanwhile, intellectual control is in charge of providing a form, a description of the location of the records, and an activity worksheet. Third, processing includes descriptions and preparation of files in the filing cabinet.

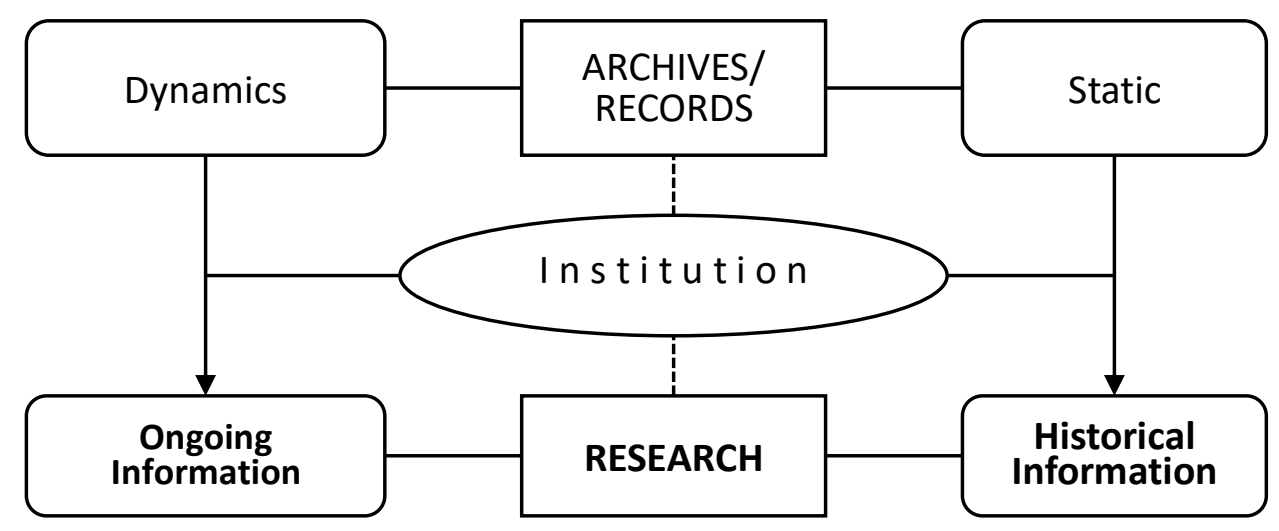

Figure 1: Archives as research information infrastructure

\section{RESEARCH METHODOLOGY}

This research used a qualitative method with a phenomenological approach. Qualitative researches are characterized by interpretive and based on natural settings, in which phenomena are seen as they are, then interpreted by researchers following the understanding of individuals and society (Denzin \& Lincoln, 1994; Laugu, 2015). The study focused on the archive as an information infrastructure and its urgency in research as a formal object, while the data sources are both informants and documents and artifacts as material objects (Ratna, 2010). The selection of informants was based on their knowledge and responsibilities in the archive. The research employed six informants consisting of archivists and users who are believed as relevant sources for this research.

This study uses three data collection techniques, namely: interviews, observation, and documentation. Interviews are questions that are asked directly or indirectly to those informants. Observation is a direct observation made by researchers in the field. Documentation refers to documents related to the formal object of research. The data was validated through triangulation techniques on three aspects, namely data sources, data collection techniques, and time. Triangulation on data sources is done by checking the data obtained through informants. Technique triangulation is done by checking data from different techniques. Meanwhile, time 
triangulation is carried out by considering the time situation through the extension of the research period (Sugiyono, 2006; Arikunto, 2010; Denzin \& Lincoln, 1994).

The data analysis of this study used the Miles and Huberman model, which includes three stages, namely data reduction, data presentation, and conclusion/verification. Data reduction is the process of directing data sets through pruning that is deemed irrelevant. Data presentation is carried out using brief descriptions, charts, and relationships between data categories. Verification is a process of taking temporary conclusions and will change when new data and facts are found related to the formal object of research (Denzin \& Lincoln, 1994; Sugiyono, 2006).

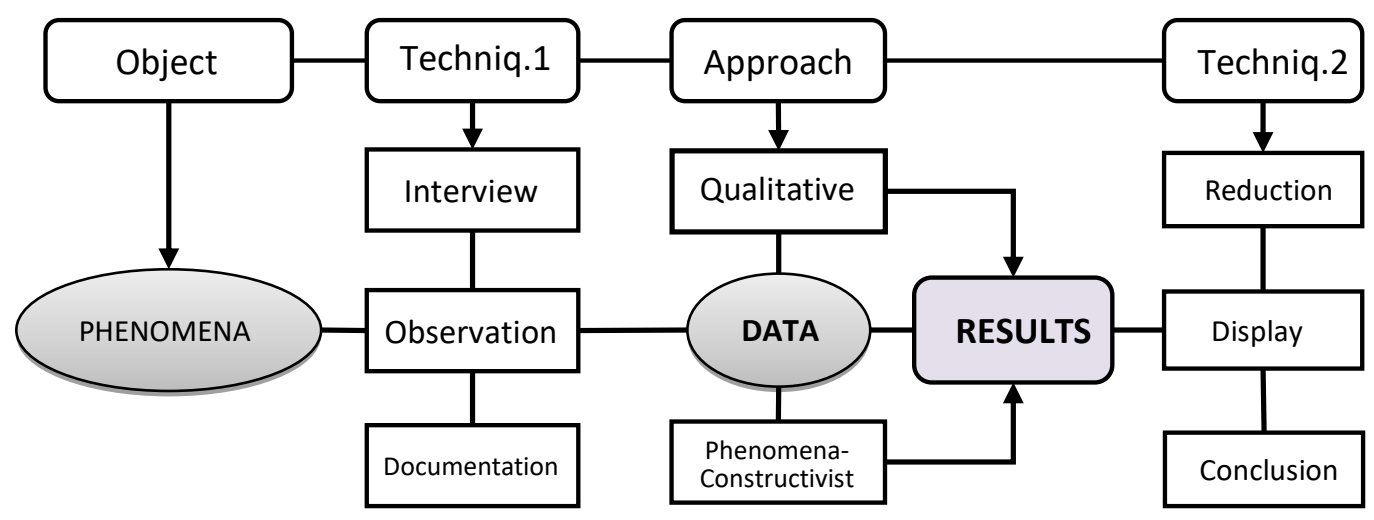

Figure 2: Research process and methodological construction

\section{RESULTS AND FINDINGS}

\section{Overview of UIN Sunan Kalijaga Archives}

UIN Sunan Kalijaga Archives has begun to be managed by an archivist since 2005 through the formation of civil servants with a background in archival education. Two years later, a guideline for classification and correspondence code was made that had received approval from the university leadership with the decree on the enactment of these guidelines in 2008. Then, in 2009, a control card system guideline was developed for correspondence and archiving, which was then developed in 2010, the control was developed into a computerized control card system. This development encourages archive staff to build collaboration with external parties in the context of developing archive governance. This encouragement was manifested in the form of cooperation with external agencies to procure an electronic document system in 2013. However, the journey encountered obstacles because it was not integrated with the technology system developed by UIN Sunan Kalijaga, so the system was no longer used.

Furthermore, the archives coordinated with PTIPD (Information Technology Centre and Data Base) UIN Sunan Kalijaga to develop an archive management system, which includes official script management and classification guidelines to replace the old classification. Finally, the system designed by PTIPD was completed and put into effect in 2015-2017. Unfortunately, the system is not optimal because it is only used to retrieve letter numbers, while the letters themselves are not uploaded into the system. Therefore, collaboration with ANRI (National Archives of the Republic of Indonesia) related to the implementation of SIKD (Dynamic Archival Information System) in the management of UIN Sunan Kalijaga Archives has begun. Since 2018, SIKD and digital signatures in correspondence have been implemented. This year also made five kinds of dynamic archive instruments, namely (1) official script management; (2) archive classification; (3) agreement between JRA and ANRI; (4) SKKAAD (Security Classification System and Dynamic Archive Access); and a manual book for the SIKD model of UIN Sunan Kalijaga (WSH Informant). 


\section{Infrastructure as an Archives Governance Formation}

Institutional infrastructure is a fundamental prerequisite for the presence of an institution and determines the ability to carry out its institutional duties and functions. An infrastructure is formed from physical and nonphysical or technical and social elements (Anderson \& Blanke, 2015). Technological means have no meaning without being interwoven with other elements, including agency and social structures. The relationship between hardware and software is what builds an infrastructure. Also, infrastructure is formed from the synergic entities between information systems and communication technology (Hanseth \& Monteiro, 1998). Thus, infrastructure is several elements, both technological and physical, such as buildings and other facilities, as well as interactional in nature, such as the presence of actors and systems that allow programs, activities, and communications to occur which are the processing stages of an organization (Shammar \& Zahary, 2019; Nurdin \& Mukhlis, 2019; Azam, 2015).

Archive infrastructure in this case is illustrated by the existence of a system and its connections as a space for the birth of archive institutional activities and technological facilities that are synergized with the system, in which actors work to answer community questions about archives. Archives of UIN Sunan Kalijaga Yogyakarta as an object of research have the potential for an information infrastructure that can guarantee the implementation of the institutional functions of archives as an information and knowledge institution, not just the preservation of cultural heritage. Its potential as an information infrastructure can be seen at least in several ways, including, among others, the availability of buildings, facilities, and status in the main institution structure of higher education. Even though the archive room is still simple, its service functions can be performed if desired as an interview with an ARS informant. It is just that, because of the lack of space, people perceive the potential as space that is only suitable for storage, not conducive to service space. As a result, the provision of such archive space is placing archives in a marginal position because the place is too small to work comfortably (Stout, 1995; Nesmith, 2002; Larsen, 2018; Lian, 2017; Levebvre, 1992).

\section{Archives as Information Infrastructure for Research}

The existence of UIN Sunan Kalijaga Archives is one of the university's information infrastructures, which has potential and significance to the dynamics of research and institutional development. This archive unit is an infrastructure in the management and use of information for various purposes, not only for a managerial function but also for a source of scientific development. Archives as records of the individual and social realities among society are a fundamental basis for documentation truth (Netshakhuma, 2019; Welland \& Cossham, 2019). This truth is important in constructing a development idea, especially the institution where the archive was born. Therefore, research and community development should place archives as a primary source in their analysis. Awareness of archives as information infrastructure will be the entrance to a process from higher education institutions to develop their world of research, which has major sources in the development of institutional science.

Archives as information infrastructure in supporting research serve as a basic force for the development of science, which is the main goal of all tertiary institutions, through their three pillars, i.e. teaching, research, and community service. The archive collection of UIN Sunan Kalijaga is managed systemically, both on dynamic archives and on static archives, although the management is still simple. Static archive management has begun to be encouraged even though attention to the status of archival institutions is still low, as seen in the archival institutions which still occupy the low-level line. At the very least, this archive management has encouraged the handling of institutional documents so that they can be maximally accessed, both for administration and research purposes. The relationship between these archives and research institutions can be seen in several ways, namely as a means of preserving the history of the institution, primary documents, and the potential driving force for institutional research.

\section{As a means of preserving the institutional history}

Archives that record every event that they experience have a high referential value to historical events. The records of these direct events make primary data have a strategic historical 
preservation function. Research on objects that contain historical elements places the archive as a strategic source to accurately reveal past events. Archives in this case have a close correlation with research and scientific development to build a path for higher education to its main vision and mission in the form of scientific development. The presence of a conducive academic atmosphere through the availability of primary institutional sources is one of the keys to achieving this goal. The existence of these primary sources is the key to preserving the history of the institution which is important in designing the future of the institution through accurate past references. This accuracy will be achieved due to the accuracy of the information obtained from university archives, which provide information that is close to events that they experienced. Furthermore, the following two informants have linked the archives with their urgency to research.

"... This archive is very important to national culture because this educational institution also refers to the culture of the community so that whatever is done is for the development of society and the nation ... therefore it is important to pay attention to archives, why? Because some researches need them to achieve rich cultural values ... this is very important...", (MKL informant).

"... The archive is very important ... because it relates to the historical values of the culture of the people in the organization. We live in an organization that is inseparable from our society so that every policy taken by the organization and recorded in the archives is a culture of society. Therefore, the importance of archives is because of the cultural elements that live in them ...", (MRW Informant).

The two interviews above refer to the same thing that archives are an important cultural heritage. Archives as cultural heritage are important objects to be preserved by a nation. Cultural heritage is a fundamental basis for seeing the identity of a nation because apart from being an object of events, it is also a subject that explains an event. The presence of university archives as a fundamental basis is a point of concern for scientific research and development. Thus, archive preservation is a strategic program to create a friendly university academic environment for research. Also, it can be seen as an important indicator for a higher education environment that lives in the world of quality research. In short, archives have an important meaning in the life of a society. University archives provide accurate information to design themselves in a competitive world. Therefore, understanding university archives means understanding the heart of the problems.

Archives as a bridge to the past for a nation have received attention so that the nation does not take the wrong steps in facing its future (Vassilakaki \& Moniarou-Papaconstantinou, 2017; Caraffa, 2018; Yap \& Barsaga, 2018). A nation needs to reflect on its past, especially in this case the university, to get valuable lessons in designing its life in the future. The past of an institution is very important for finding the best way to face various challenges because the past will help to choose various experience options that are appropriate to the circumstances of the institution. A university developing its archives means that it has built a past that will guide it on its future. What the UIN Sunan Kalijaga Archives has done is an effort to protect its past as a source of information that can be used to make the right decisions for the future (Vaujany, Vaast, Clegg, \& Aroles, 2020; Netshakhuma, 2020).

In addition, archives also function as information curation to maintain the availability of accurate information. Archive curation is an effort to maintain the accuracy of the information for an institution, especially at university archives. Over time, it has been recorded in history about the ups and downs of an educational institution, especially universities. The existence of archives at this institution has provided fact stories about the development of decisions and policies it has taken in solving any problems. The availability of this archive also provides preserved information, because one of its functions is curating information. Meanwhile, information curation serves to ensure that information can be held accurately. So, university archives as information curation have described a preservation process of one of the institutional historical elements that occurred at the university education levels. 


\section{As Primary Documents for Institutional Research}

All documents regarding program processes and activities carried out at tertiary institutions can be ascertained as material that has primary information. These data are primary sources in knowledge management that can be done through research and the development of science. In principle, UIN Sunan Kalijaga Archives as an institution has a standard organizational governance mechanism to support the running process of higher education institutions. Each of these actions is recorded in various documents that have a level of benefit for the sustainability of the institution. To achieve a greater level of benefit, university archives seek to create conditions that drive the dynamic processes of an organization to achieve its vision and mission.

As primary data, archives are documents that provide the first information on all institutional activities. Starting from the issue of the university's three pillars to that of administration, archives are an inseparable element. The archive is a record of every event, both small and large, which clearly describes the event in question (Jeon, 2011; Sande, Verborgh, Hochstenbach, \& Sompel, 2018). These archival documents exist in various forms, including deeds, certificates, correspondence, minutes, reports, and even certain publications, as well as other documents that are not publicly published. Also, other publications were found that even resembled or duplicated collections owned by libraries, due to some reasons. For example, a collection of student final assignments from undergraduate to doctoral degrees can be collected by archives as an effort to preserve.

According to several informants, these documents can be stored in archives because they are considered to have historical institutional value and some of them are not in the library. The collection is a single collection, not elsewhere, so the archival institution is responsible for preserving these historical documents. The proximity of this document to the conditions it describes makes it a primary source in the field of research. Although the function of historical preservation is highly emphasized, aspects of its services are very low due to the limited staff available. In addition, the potential static files are still very limited, except for PMU (Project Management Unit) reports. As for the archival documents regarding the deeds of the establishment of universities and other institutions, photos of activities, etc. are still at the creator of the archives.

Likewise, archives of meeting minutes, institution deeds and agreements, photographs, and the like are very important in understanding the issues that have been discussed among policymakers and other stakeholders in the past. This information is important for researchers who wish to view institutional policy developments as a basis for designing new future policy models rooted in past conditions. Apart from the research function, archives also provide opportunities for lecturers who wish to develop their courses through archival sources. Educational archives owned by these archival institutions can be used as a reference source for lecturers who are looking for materials, especially those related to historical sources in the field of education. The condition of UIN Sunan Kalijaga Archives still needs to be addressed on all fronts, as shown in the interview with the following informants.

"... archives have not been opened to the public, as libraries do, because the collections of static archives have not been handled optimally, not to mention that the staff who handle it are very limited, ... they are still busy with dynamic archives that must be handled, so this seems that there must be a solution immediately so that this static archive can be used as a source of information that can help researchers for doing research...", (WSH Informant).

In addition, other informants also said that archives relating to the development from IAIN to UIN were rich in information. Unfortunately, this archive has not been fully processed which is designed to assist researchers. According to him, PMU reports which contain about the transformation of education from IAIN to UIN Sunan Kalijaga Yogyakarta are very important, if viewed from the world of archives because complete information can only be traced through this archive. If there are researchers who want to learn about how and what happened during the development process, then this archive is the key. In essence, this document has an accurate and formal history of the development of educational institutions at UIN Sunan Kalijaga Yogyakarta. 


\section{As Capital for Institutional Research Development}

The existence of university archives has an important role in developing institutional research at the university where the archive was born. The availability of complete university archives opens up great opportunities for research because the archives contain a variety of information regarding academic and non-academic issues. Academic issues include all activities to encourage and produce knowledge, which is contained in the three pillars of higher education, i.e., education and teaching, research and development of knowledge, and community service. Meanwhile, non-academics are activities that function to improve the abilities, talents, and interests of the academic community. All of these activities are recorded at the university archives, ranging from small issues to big university problems. Archives as a source of information have a high degree of primary accuracy toward the institutional reality it describes.

The existence of the UIN Sunan Kalijaga Archive as a capital for institutional research development can be seen from two aspects, namely internal and external. Internally, there are two dominant things, namely the desire of stakeholders to develop, one of which departs from university archive information and the existence of archival documents owned by the institution. The first thing is related to the desire of stakeholders to develop archive-based research. For this, the archives of UIN Sunan Kalijaga are still not maximal because of the simplicity of the archive organs they have, as well as the space that can accommodate the needs of researchers to utilize the limited archives. However, the potential in this direction can be seen from the following interviews.

"... there are a lot of static archives or static potential we have, but they are still in the archive creation units ... as archivists, we are ready to provide services for research data, but unfortunately we don't have the power because we don't have a legal standing yet, ... such an organization that supports us in doing it all. In addition, the three of us still only handle archives that are still actively used by the creation units, such as the financial department ... the main one ...", (DHH Informant).

Based on the interview above, it is clearly illustrated that the potential for static archives already exists in the UIN Sunan Kalijaga environment. It is just that the legal standing in the form of an archive unit as a formal institution does not yet have a strong recognition within the framework of its structural organization, so the management of archives has not been carried out properly. It is different from library institutions which already have special heads and staff. Therefore, the obvious obstacle to UIN Sunan Kalijaga archives is the absence of an official organ to accommodate the needs of static archives, so starting from the procurement, processing, and up to the service of archives will be forever problematic, until the organ can be realized, which will later have functional responsibilities as other institutions or units (Larsen, 2018). The existence of archival collections is also an internal factor that encourages institutional research. In general, UIN Sunan Kalijaga Archives has a dynamic collection of static archive sources. It is just that broad and comprehensive authority has not been given to all units that create archives due to legality reasons.

Meanwhile, external factors come from the influence of external institutions with relevant relationships, such as ANRI and other university archives. The relationship between these archives and other archival and information institutions is used as a lesson for sparking the development of UIN Sunan Kalijaga university archives. The collaboration that was built together with ANRI is a learning moment for UIN Sunan Kalijaga Archives. From the external factors above, it is found that there is the involvement of the National Archives related to the formulation of archive retention schedules. The National Archives in this case has a regulatory intervention toward university archives. So, the archive retention schedule of UIN Sunan Kalijaga Archives must go through the approval of the Indonesian National Archives.

The emergence of discourses on the development of archives, especially university archives in various places, is also one of the factors that support efforts to develop archives as an institution. The discourses on archival development go hand in hand with the development of libraries, information, museums, and galleries. Institutions that have the substance of collections 
are starting to move to ensure that they can provide benefits to users, especially in the world of scientific research and development. Therefore, the development of archives through strengthening the status of the organization needs to be considered in the context of developing archives that are not only oriented towards historical curators and preservation but also develop towards public services, as information infrastructure to assist research development, especially at universities. This means that significant archive management is developed to contribute to the world of higher education related to efforts to achieve its vision and mission as an industry of education and producer of knowledge.

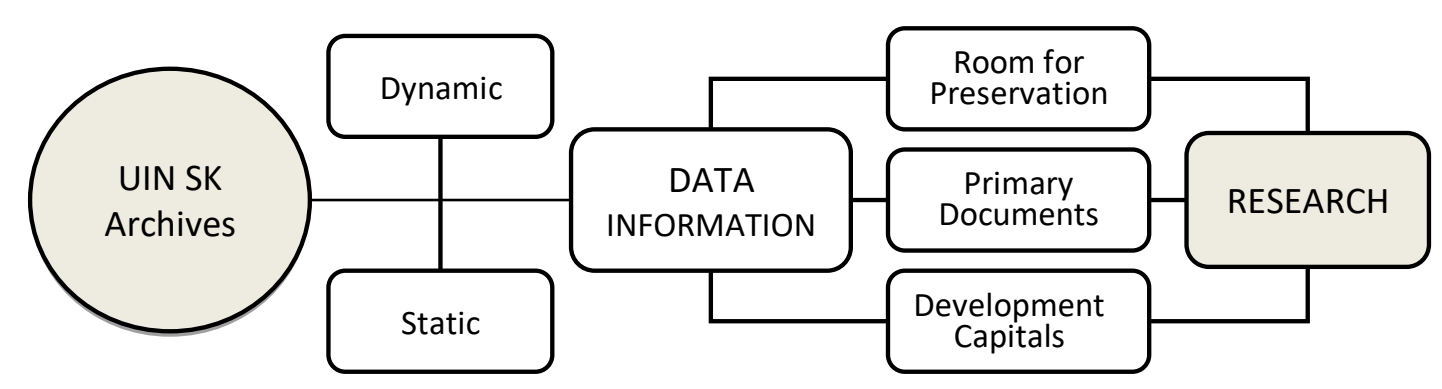

Figure 3: Core of information archival infrastructure in research

\section{CONCLUSION}

The management of university archives is very urgent because the presence of archives is regarded as an information infrastructure in running the wheels of the organization as well as recording all policies and organizational activities. This is illustrated in the explanation of the results and analysis of the research above, which shows the urgency of archives, especially in the world of institutional research. This urgency is seen in its framework as an information infrastructure for research in higher education. First, its presence shows the intertwining elements in the context of agency and social structure, which shows its information functions, as an institution of information, knowledge, and cultural heritage preservation. Second, the position of the information infrastructure illustrates three main patterns. The first one is as a means of preserving the history of the institution, which shows its relation to the management and use of information that is manifested in various interests, such as managerial functions and sources of scientific development. The second pattern is as the primary document for institutional research, by which archives are a record of every event, both small and large, which depicts organizational events. Finally, as a capital for institutional research development, archives contain a variety of information relating to academic and non-academic issues of the institution.

\section{REFERENCES}

Anderson, S., \& Blanke, T. (2015). Infrastructure as intermediation - from archives to research infrastructures. Journal of Documentation, 71(6), 1183-1202.

Arikunto, S. (2010). Prosedur penelitian: Suatu pendekatan praktik. Jakarta: Rineka Cipta.

Azam, M. S. (2015). Diffusion of ICT and SME performance. Firms in Developing Nations Advances in Business Marketing \& Purchasing, 23A(7), 290.

Beard, F. (2018). Archiving the archives: The world's collections of historical advertisements and marketing ephemera. Journal of Historical Research in Marketing, 10(1), 86-106. doi:10.1108/JHRM-08-2017-0044

Blendon, E. J. (1975). University archives: A reason for existence. The American Archivist, 38(2 (Apr.)), 175-180.

Blouin, F. X. (1999). Archivists, mediation, and constructs of social memory. Archival Issues, 24(2), 101-112. 
Caraffa, C. (2018). Photographs as documents/photographs as objects: Photo archives, art history and the material approach. Collection and Curation, 37(4), 146-150.

Denzin, N. K., \& Lincoln, Y. S. (1994). Handbook of qualitative research. London: Sage Publication.

Hanseth, \& Monteiro, E. (1998, August). Understanding information infrastructure. Manustcript 27.

Hunter, G. S. (2003). Developing and maintaining practical archives: A how-to-do-it manual (how-to-do-it manuals for libraries). New York: Neal-Schuman Publishers.

Indonesia. (2009). Undang-undang Republik Indonesia nomor 43 tahun 2009 tentang kearsipan. doi:https://www.kpk.go.id/images/pdf/uu\%20pip/UU_No_43_Tahun_2009_Kearsipan. pdf

Jeon, J. J. (2011). Memories of memories: Historicity, nostalgia, and archive in Bong Joon-ho's "Memoriesof Murder". Cinema Journal, 51(1 (Fall)), 75-95.

Jones, C. J. (2010). Archival data: Advantages and disadvantages for research in psychology. Social and Personality Psychology Compass, 4(11). doi:10.1111/j.17519004.2010.00317.x

Larsen, H. (2018). Archives, libraries and museums in the Nordic model of the public sphere. Journal of Documentation, 74(1), 187-194. doi:10.1108/JD-12-2016-0148

Laugu, N. (2015). Representasi kuasa dalam pengelolaan perpustakaan: Studi kasus pada perpustakaan perguruan tinggi Islam di Yogyakarta. Yogyakarta: Gapernus Press.

Levebvre, H. (1992). The production of space. Cambridge: Basil Blackwell.

Lian, Z. (2017). The creation, preservation and transmission of Shuishu archives in China. Journal of Documentation, 73(6), 1192-1208. doi:10.1108/JD-11-2016-0143

Mirwani, A. (2014). Deskripsi dan penataan arsip statis. Banten: UT.

Nesmith, T. (2002). Seeing archives: Postmodernism and the changing intellectual place of archives. The American Archivist, 65(1 (Spring-Summer)), 24-41.

Netshakhuma, N. S. (2019b). The role of archives and records management legislation after colonialism in Africa: Case of Southern Africa. Records Management Journal, 29(1/2), 210-223. doi:10.1108/RMJ-09-2018-00

Netshakhuma, N. S. (2020). Responsibilities of archivist now and in the future as the result of COVID - 19; Case of ICA-SUV. Digital Library Perspectives, ahead-of-print(ahead-ofprint). doi:10.1108/DLP-06-2020-0050

Noble, D. F. (1977). Higher education as an industrial process: What university archives reveal about the history of corporate, scientific America. The Midwestern Archivist, 2(2), 35 53.

Nurdin, L., \& Mukhlis, S. (2019). Institutional repository as an information infrastructure for scholarly communication: An exploratory study in Indonesia. Malaysian Journal of Library \& Information Science, 24(3), 101-114. doi:10.22452/mjlis.vol24no3.6

Purcell, A. D. (2012). Academic archives: Managing the next generation of college and university archives, records, and special collections. Chicago: Neal-Schuman.

Ratna, N. K. (2010). Metodologi penelitian: Kajian budaya dan ilmu sosial humaniora pada umumnya. Yogyakarta: Pustaka Pelajar.

Sande, M. V., Verborgh, R., Hochstenbach, P., \& Sompel, H. V. (2018). Toward sustainable publishing and querying of distributed linked data archives. Journal of Documentation, 74(1), 195-222. doi:10.1108/JD-03-2017-0040

Shammar, E. A., \& Zahary, A. T. (2019). The internet of things (IoT): A survey of techniques, operating systems, and trends. Library Hi Tech DOI. doi:10.1108/LHT-12-2018-0200

Stout, L. (1995). The role of university archives in the campus information environment. The American Archivist, 58(2 (Spring)).

Sugiyono. (2006). Metode penelitian kuantitatif, kualitatif, dan R \& D. Bandung: Alfabeta.

Vassilakaki, E., \& Moniarou-Papaconstantinou, V. (2017). Beyond preservation: Investigating the roles of archivist. Library Review, 66(3), 110-126.

Vaujany, F.-X. d., Vaast, E., Clegg, S. R., \& Aroles, J. (2020). Organizational memorialization: Spatial history and legitimation as chiasms. Qualitative Research in Organizations and 
Management: An International Journal, ahead-of-print(ahead-of-print). doi:10.1108/QROM-01-2020-1887

Welland, S., \& Cossham, A. (2019). Defining the undefinable: Analysis of definitions of community archives. Global Knowledge, Memory and communication, 68(8/9), 617634. doi:10.1108/GKMC-04-2019-0049

Widarno, d. (2010). Organisasi tata laksana dan lembaga kearsipan. Jakarta: Universitas Terbuka.

Wursanto, I. (1991). Kearsipan. Yogyakarta: Kanisius.

Yap, Y. M., \& Barsaga, A. S. (2018). Building a timeless audiovisual collection: libraries and archives as repositories of oral history. Library Management, 39(3/4), 188-199. 